\title{
Branding Rio, Brazil and the environment: A global media coverage of the 2016 Summer Olympics opening ceremony
}

\author{
Radoslaw Sajna* \\ *Professor, Kazimierz Wielki University in Bydgoszcz, Poland
}

Abstract

\begin{abstract}
The Olympic Games are always a great opportunity to brand the city and country hosting such a big global event. The opening ceremony of the Rio 2016 Summer Olympics was the best moment to show different values and images of Rio de Janeiro and Brazil, but also to promote a global environmental idea with the message "let's save the planet". Global media coverage of the ceremony should strengthen the messages. In this article an analysis of 30 articles published in 30 different newspapers (online) from different continents, reporting the opening ceremony, has been made to answer the question: how important were the environmental issues, comparing with presentations of different values of Rio and Brazil, in the global media coverage of the event. In concrete: did the global media coverage of the opening ceremony serve above all for branding Rio and Brazil or for promoting environmental issues as an important global problem? The results show that Rio and Brazil brands were promoted strongly (however with some critical views in different articles), while the environmental issues were mentioned in most articles, but highlighted only in a few of them.
\end{abstract}

Keywords: Brazil, environment, media, Olympic Games, Rio 2016, Rio de Janeiro

\section{Introduction}

For many people around the world Rio de Janeiro is known because of a fabulous carnival and a big statue of Christ the Redeemer on the Corcovado mountain. For specialists in the field of environmental protection, however, Rio de Janeiro is also known as the host city of the Earth Summit in 1992. That global event, officially: the United Nations Conference on Environment and Development (UNCED), was organized to promote a global idea of the sustainable development. It was a turning point for this global issue, and 20 years later, in 2012, Rio de Janeiro hosted the next summit, called Rio+20, officially: the United Nations Conference on Sustainable Development. This big Brazilian city is a good place to host such events, because of environmental connotations: Brazil is a country of the richest nature heritage, with the Amazonian rainforest being the largest and most biodiverse tropical forest in the world (though threatened still, because of climate change and deforestation).

In 2016 Rio de Janeiro hosted a truly global event once again, this time the Summer Olympic Games. For every city, hosting such a sport event, broadcast globally thanks to modern media technologies, to almost every corner of the world, is a great opportunity to promote the city and the country where the Olympics are held. Nevertheless, it is also an occasion to promote ideas, alongside the pacifist idea of sports competition with the principles of fair play. The best moment for that is the Olympic Games opening ceremony, broadcast live and covered globally by the media. In the case of the Rio 2016 the opening ceremony was fabulous as the Rio carnival, and, without a doubt, it was skillfully used as a "tool" promoting Rio, Brazil and environmental issues. 
The purpose of this article is to present the results of research on the global media coverage of the Rio Olympics opening ceremony in order to answer the question: how important the environmental issues were, compared to the promotion of Rio and Brazil, in the media reports of this global event.

\section{Olympic Games and branding cities, countries and global ideas}

Keith Dinnie, an expert in branding cities, states: "The hosting of events is seen by many cities as an important element of the city brand-building process. (...) The hosting of a mega event such as the Olympic Games is much sought after by cities that compete aggressively for the right to host them" (Dinnie 2011: 96). It would be difficult to disagree with this view, though among other global events that generate meaningful economic and promotional benefits are also the EXPO exhibitions, Miss World competitions or football World Cups (Proszowska-Sala, Florek 2010: 211). Nevertheless, Olympic Games have more global media impact that the three events mentioned above, because the EXPOs are not transmitted live, Miss World competitions are only one-day events, and in the football World Cups a limited number of countries participate, while in the Olympic Games almost all countries of the world (at least nowadays).

In some cases global events are elements of an overall goal of creating a new image of a country. This is a case, for example, of Spain after the collapse of General Francisco Franco's regime in 1975 that meant a transition process toward democracy. Melissa Aronczyk explains: "Aside from the major changes in political structure, the next twenty-five years saw revolutions in the areas of cultural production (the Bilbao museum, the films of Pedro Almodóvar, the fashion of Agatha Ruiz de la Prada), architecture (Santiago Calatrava's Telefónica communications tower, the Velodrome by Esteve Bonell and Francesc Rius, the Agbar skyscraper), economy (the revitalization of cities through increased spending by the public and private sectors on infrastructure and institutional and tourist advertising, the privatization and transnationalization of Spanish multinational companies), and international attractions (the 1992 Barcelona Olympic Games, the 1982 FIFA World Cup of soccer, the 1992 International Expo in Seville)" (Aronczyk 2013: 34-35). Indeed, the Olympic Games in Barcelona in 1992 were to promote not only this Catalan largest city, but also a new Spain (Catalonia being still a part of it). For Barcelona itself, however: "The Olympic Games helped to completely re-imagine the city and present it on the international scene as a modern capital, creative, innovative, welcoming, daring, cosmopolitan, initiative-taking, with its own style, and as a city with an excellent quality of life, developing a great feeling of self-esteem and pride on the part of the citizens. Only 13 years after the arrival of democracy in Spain, the objectives of transforming and repositioning the city on an international scale had been accomplished and Barcelona had positioned itself amongst the leading cities of the world" (Belloso 2011: 121).

The famous Spanish architect Santiago Calatrava, mentioned earlier, was responsible for design project of the Olympic stadium for the first Olympic Games in $21^{\text {st }}$ Century, in Athens, Greece. This city is the best example of branding by Olympics, because of its historic heritage, though in the Antiquity the most important sport games were in Olympia, on the Peloponnese peninsula, and not in Athens. Nevertheless, the Panathenaic Stadium, re-build for the first modern Olympic Games in 1896, became one of the most iconic buildings of the Greek capital, and one of the most iconic buildings of sport ever. In accordance with David Goldblatt, the Olympics of 1896 "were international games, but they were also understood as a peculiarly 
Greek triumph" (Goldblatt 2016: 50-51). Of course, the global media impact in $19^{\text {th }}$ Century was poor, in contrast to the Olympic Games in Athens in 2004. During more than one hundred years, the media technologies have developed to make global sport events truly global for global public. Maria Fola underlines the media attention that the "successful mega event" of the Athens Olympics attracted worldwide, though she considers that "after the Games, Athens did not have any further stories to tell that were strategically generated, served a specific media agenda, or aimed to promote consistent strategic objectives" (Fola 2011: 116). In accordance with David Goldblatt, every next Olympics are broadcast to more countries, and the hours of TV-viewing are growing too: "Barcelona was broadcast to 160 countries, Atlanta to 216 and Sydney to 220, almost the entire planet. The cumulative viewing hours of the Seoul games was 10.4 billion, rising to 19.6 billion for Atlanta and 34 billion for Athens" (Goldblatt 2016: 336).

Although the essence of the Olympic Games is sport rivalry, it seems that the most meaningful moment of every Games of this kind is the opening ceremony. The highest TV-viewing figures of the Olympics were recorded exactly by the opening ceremonies (Goldblatt 2016: 337). The people around the world, waiting four years for the Olympics, began this global event experience with truly global transmission from the hosting city, where the Olympic Flame is to be light after a torch relay from Olympia. This tradition, commemorating ancient Greek story of theft of fire from Zeus by Prometheus, was first performed at the Olympic Games in Berlin, in 1936, during Hitler's Nazi regime. In accordance with Joseph Goebbels' (responsible for the Nazis propaganda) memories, already in August 1935 Leni Riefenstahl received an order from Hitler to make a film about the Berlin Games (Longerich 2014: 411). The film was made, of course, for propagandistic purposes. David Goldblatt explains: "Her great achievement was to transform the material of the Berlin opening ceremony into a film so powerful, and so widely viewed, that it extinguished any other memory or version of the moment - a task made infinitely easier by the absence of television" (Goldblatt 2016: 396). Today the opening ceremonies are gigantic initiatives, directed by famous artists, and the costs are overwhelming. For the last Winter Olympic Games opening ceremonies Torino (2006) spent around 20 million dollars, Vancouver (2010) around 30 million, and Sochi (2014) at least 100 million! In the case of the Sochi Olympics the opening ceremony was used as a big propaganda event demonstrating Russian heritage and power. The opening ceremony of the Summer Olympic Games in Beijing (2008), however, costed even more: 150 million dollars, while in London (2012) "only" 45 million (Goldblatt 2016: 396-397). Although the money could help to prepare spectacular opening ceremonies, the most important is to show ideas to the people around the world. Authoritarian or totalitarian regimes tried to demonstrate their powers, above all, and every country hosting Olympics promotes its culture, history or achievements, linking it to popular ideas of the moment. Maria Fola (2011: 115-116) describes the case of the meaningfully symbolic Athenian Olympics 2004:

"The widely praised Opening Ceremony by avant-garde choreographer Dimitris Papaioannu successfully linked the heritage of the Olympic city to contemporary concepts in a truly unique way. The story began with a 28-second countdown (the number of the Olympiads up to then) paced by the sounds of an amplified heartbeat played by two drummers, one located in the main stadium and another one located in Olympia, the venue of the ancient Olympic Games. (...) Finally, all the characters of the parade began to walk towards the center of the stadium, mixing the past and the present in a single marching beat of the drums". 
The opening ceremony of the Rio Olympic Games, celebrated on August 5, 2016, was also artistically interesting, with images presenting Rio de Janeiro, Brazilian culture and history, but it was focused also on the environment, that is an important part of the Brazilian heritage, indeed. Although the nature and environmental issues appeared in previous Olympics, it was in Rio that, for the first time, the opening ceremony was full of greenness, including a call to protect the environment and prevent global warming. The first image transmitted worldwide from Rio 2016 was a big, green pacifistic symbol, made of trees on the Maracanã Stadium. Previously, at Lillehammer (Winter Olympic Games 1994) there was "an unprecedented commitment to thinking through the environmental implications of the games" (Goldblatt 2016: 370), the Sydney 2000 Olympics were "green" too, and for the Olympics in London 2012 a special Olympic Park area project was to "establish the London Olympics as the most sustainable Olympic games and a model regeneration project" (Ween 2012: 190). For the Olympics in Rio a special Sustainability Management Plan was prepared and special images from the opening ceremony were presented to global audience, in order to show the environmental heritage of Brazil and to promote global environmental ideas. The first Olympic Games in South America began with a loud pro-ecological appeal. And the Olympic movement, in accordance with D. Goldblatt, "came to rely rhetorically on other benefits of hosting the games: in particular, the environmental improvements that came with hosting the Olympics, and the sporting and social legacies that the games could leave behind" (Goldblatt 2016: 393).

\section{Media and environment}

While many athletes participated in the Olympic Games in Ancient Greece (Plato included!), Aristotle preferred to dedicate himself to philosophy and research on natural phenomena. His books about animals (Historia Animalium, De Patribus Animalium, De Motu Animalium etc.), like books of the "father of botany" Theophrastus (De historia plantarum, De causis plantarum), are among the first "famous" written works about nature and the environment. In Ancient Rome a thirty-seven-book encyclopedia Historia Naturalis, written by Pliny the Elder, appeared. Mark Neuzil noticed: "As a journalism forerunner, Pliny demonstrated an awareness of both environmental damage and its causes. (...) He was a keen observer of weather, noticing that rainbows occur only opposite the sun, at a place high in the sky when the sun is low or low in the sky when the sun is high. His practical advice on making glue from ox hides, raising bees, cultivating grapes and figs, preserving food, and using flax to make linen had value for hundreds of years. (...) Pliny was among the pioneers in writing about exotic species, a popular subject among science and environmental writers of the modern period" (Neuzil 2008: 38).

In the Renaissance epoch many ancient works reappeared, but also many new books about nature were written, by Leonhart Fuchs, Ulisses Aldrovandi, Pierre Belon or Konrad Gessner. Johannes Gutenberg's invention of mechanical printing made possible to produce periodicals that began to appear in Europe in the $17^{\text {th }}$ century. During the Illustration and the following $19^{\text {th }}$ century a lot of books and press articles about various aspects of nature were published, and some scientists dealing with natural phenomena became famous, like Carl Linnaeus, Alexander von Humboldt or Charles Darwin, to name only a few of the most important. Many newspapers promoted scientific theories and ideas about nature, agriculture or the 
environment. Nevertheless, as Libby Lester states: "There is little agreement on when 'the environment' began. It could have been 1962 when Rachel Carson published Silent Spring with its compelling opening fable connecting human activity, science and nature" (Lester 2010: 17). William Cronon (2008: ix) explains:

"It may be an oversimplification to say that the modern environmental movement began with Rachel Carson's Silent Spring, but it is hard to overstate that book's impact. Prior to its publication in 1962, various environmental concerns were becoming more prominent in the years following World War II. (...) But Silent Spring was a lightning rod like no other. Gaining visibility first as a series of articles in the New Yorker and then as a best-selling book, it catapulted its author (...) into a political firestorm. Carson's indictment of DDT and other insecticides brought heated rebuttals from chemical companies that manufactured these products, from government agencies that promoted their use, and from scientists who believed that their benefits far outweighed their harms".

Although different media reported environmental issues before and after the Rachel Carson's book, it was during the Earth Summit in Rio de Janeiro in 1992 when the environmental journalism really started (Parratt 2006: 17). The media not only presented the idea of the sustainable development to wider audiences, but also began to treat seriously various environmental issues. Thanks to the "new media" even an alternative public sphere of environmental communication has developed, with environmental blogosphere or many online news services, and professional societies for environmental journalists appeared (Cox 2010: 167173). Al Gore's film and book from 2006, entitled "Un Inconvenient Truth" (followed by the Nobel Peace Prize awarded to him in 2007), attracted stronger media attention to the problem of climate change. In consequence the media audiences became more conscious of the issue. Indeed, in accordance with a survey of Eurobarometer (2007), the climate change has become the main environmental issue that European citizens are worried about (it was indicated by 57 per cent of respondents, while in 2004 only by 45 per cent). Some global surveys have confirmed that concerns about the environment have been growing in the first decade of the $21^{\text {st }}$ century on a wider global scale (Hansen 2010: 163-164). Obviously, this is an effect of the media influence on global public opinion. Of course, the media around the world use different frames to present the problem, so some global pluralism on the issue of the climate change and global warming exists, though more emphasis on the problem is laid by the media in the developed countries of Europe and America, than in, for example, poor (however rich in nature) African countries (see: Sajna 2012: 71-83). The media and environmental journalism have become one of the main areas of study within a wider field of the environmental communication. Robert Cox explains: "In many ways, the study of environmental media has become its own subfield. It focuses on the ways in which the news, advertising, commercial programs, and Internet sites portray nature and environmental problems. It is also the study of the effects of the media on public attitudes" (Cox 2010: 17). 


\section{Methods}

Various methods are used in studies on environmental communication. In this study, focused on media coverage of the Rio Summer Olympic Games opening ceremony, quantity and quality content analyzes have been used. Various articles (with photos) that appeared on official websites of different opinion daily newspapers around the world, directly after the ceremony, have been analyzed. A sample of thirty newspapers from different countries, representing different continents, world regions, political and media systems, political biases, languages or cultural and religious backgrounds was selected. Since the Olympic Games were held for the first time in South America, a sample from that continent is strongly represented (maybe overrepresented), because eight of thirty dailies are from Southern American countries: "O Globo" (Brazil), "La Nación" (Argentina), "El Tiempo" (Colombia), "El Universal" (Venezuela), "El Mercurio" (Chile), "El Comercio" (Peru), "El Universo" (Ecuador) and "ABC Color" (Paraguay). Additionally, two dailies from another Latin American countries were selected: "El Universal" (Mexico) and "Granma" (Cuba), as well as "The New York Times" (USA) and "Le Devoir" (Canada) from North America. From Europe: "The Daily Telegraph" (Great Britain), "Le Figaro" (France), "El Mundo" (Spain), "Diário de Notícias" (Portugal), "Corriere della Sera" (Italy), "Rzeczpospolita" (Poland), "Le Soir" (Belgium), "Le Temps" (Switzerland), "The Irish Independent" (Ireland) and "L'Osservatore Romano" (Vatican). From Asia: "China Daily" (China), "Hindustan Times" (India), "The Jakarta Post" (Indonesia), "The Nation" (Thailand), "The Japan Times" (Japan) and also: the Egyptian daily "Al Ahram", representing the Middle East. "The Guardian" was selected from the most populous African country that is Nigeria, and "The Age" from Australia. Of course, this sample is limited, but representing a wide spectrum of world regions, countries and cultures.

The analysis of these online newspapers is based on three steps.

Firstly: headlines of the articles. The question is: did the words "Rio", "Brazil" (in appropriate languages) or some references to the environmental issues, presented during the ceremony, appear in the headlines? This is the starting point for analyzing the promotional impact of the articles. Using certain words with positive associations makes them positive in the recipient's consciousness. Assuming that the Olympic Games have a generally positive image, using the name of the city (Rio) or country (Brazil) in conjunction with this global sport event makes them also positive. The same when the Olympics are linked to other ideas, such as the environmental issues in this case. A quantitative analysis has been appropriate at this stage of the research. Secondly: content of the articles. The question is: were the articles focused strongly on the values of Rio or Brazil or on the environmental issues presented during the ceremony? Each article has been read in its entirety to answer this question. Of course, the articles reported the same event, but they could focus on different aspects of the ceremony that lasted several hours. A qualitative analysis has been aimed at determining to what extent the values of the hosting city (Rio) and country (Brazil), deliberately promoted during the ceremony, were reflected in the articles. Next question: how much the environmental issues, also deliberately promoted during the ceremony, could be found in the analyzed texts?

Thirdly: photos published with articles. The question is: did the photos show the values of Rio, Brazil or the environmental issues presented during the ceremony? In this case a visual analysis has been easy and difficult at the same time, because in some cases a gallery of pictures was published, and it has been problematic to determine which photos could be treated as main pictures of the ceremony. Nevertheless, in most cases, the question regarding this element of the research could be answered. 
All the questions of the research have been helpful to answer the main question of this study that is: did the global media coverage of the Rio Olympic Games opening ceremony primarily serve for branding Rio and Brazil or rather for promoting environmental issues as an important global problem?

\section{Results}

The word "Rio" appeared in 20 headlines out of 30 analyzed articles from different continents, while "Brazil" only in 4. In three cases both words were mentioned: in the Italian daily newspaper "Corriere della Sera" (www.corriere.it), the Indian "The Hindustan Times" (www.hindustantimes.com) and the Egyptian "Al Ahram" (http://english.ahram.org.eg) [See: 'List of analyzed articles' after 'References' at the end of the article]. This Egyptian newspaper was the only one which included (at least on its English-language website that was analyzed) in its headline both "Rio" and "Brazil", as well as a reference to the environment: "Rio Olympics opening ceremony highlights Brazil, environment". The environmental references appeared only in 6 headlines, so 5 beside of "Al Ahram". One case was from South America. The Paraguayan newspaper "ABC Color" (www.abc.com.py) posted a headline: "Música, arte y ecologismo en inauguración de Juegos" ("Music, art and environmentalism in the Games inauguration"). Another case was from Europe. The Spanish newspaper "El Mundo" (www.elmundo.es) published an article with a suggestive headline: "Una ceremonia sostenible entre la selva de atletas" ("A sustainable ceremony among a selva of athletes"). On the website of "The Jakarta Post" (www.thejakartapost.com) from Indonesia one could read the headline: "Rio welcomes world with sultry music, plea for conservation". "The Japan Times" (www.japantimes.co.jp) posted another headline: "Rio Olympics open with ceremony focused on environment". "The Age" (www.theage.com.au) from Australia, however, proposed a more metaphorical headline: "First green, now gold: the climate changes in Rio". These six headlines made references to the environmental issues explicitly presented during the opening ceremony of the Olympic Games in Rio, while in the rest of the analyzed headlines no such mentions could be found.

The word "Rio" were used most frequently in the headlines, above all in expressions like "Rio 2016", "Rio Olympics" or "Rio Games". Therefore it could be stated that the headlines of the analyzed articles served more for promotion of Rio de Janeiro, through positive association with the Olympic Games, than for promotion of Brazil or the environmental issues, mentioned, respectively, only 4 and 6 times in the headlines, while "Rio" 20 times. Some of the headlines were evidently promotional for Rio de Janeiro, branding this city as open to the world (like for example in the Mexican daily "El Universal", www.eluniversal.com.mx, with the headline: "Río de Janeiro acoge al mundo", that means: "Rio de Janeiro welcomes the world") or even as the best place in the world, like in a Gilberto Gil's song, quoted in the headline of the prestige Argentine newspaper "La Nación" (www.lanacion.com.ar).

In the analyzed articles, contrary to the headlines, Brazil is present more frequently than Rio de Janeiro. The historical, cultural and natural values of the biggest South American country were shown during the Olympic Games opening ceremony, and in most of the analyzed articles these attractive images and sounds of the show were described. Nevertheless, in several articles some critical views on Brazil, as well as Rio, were included. "The New York Times" (www.nytimes.com), a leading prestigious newspaper from the United 
States, began its article, titled "A Gilded Olympics Begin With the Opening Ceremony in Gritty Rio" with these words (Romero 2016):

"If there was a nation in need of an uplifting spectacle at this moment, even in the form of a public relations exercise, it was Brazil.

The first South American country to host the Olympics is reeling from an astonishing combination of political upheaval and economic crisis. Its efforts to stage the world's biggest sporting event met trouble at every turn, from the Zika virus to polluted waters to budget cuts so deep that basic operations became strained (...)".

The article in the most popular British prestigious daily newspaper, that is "The Daily Telegraph" (www.telegraph.co.uk), titled: "Rio Olympics 2016 opening ceremony kicks off with a vibrant bang - and unfortunate reminders of troubled backdrop to the Games", was more balanced, focusing on different aspects of the show and reality. The first words of the texts were (Tyers 2016):

"Rio Olympics officially open after mixed opening ceremony.

The Rio Olympics officially started with a long and loud celebration of Brazilian culture that also featured some unfortunate reminders of the troubled backdrop to these Games. (...)"

And then:

"...the boos that greeted acting Brazilian president Michel Temer's short address to open the Games, the smattering of jeers the Russian team received and the catcalls that followed a reference to government funding tell a different story.

Rio 2016 has had a difficult upbringing with worries about the country's ability to afford it, Rio's preparations and sport's credibility in the face of a divisive doping crisis, but South America's first ever Olympics is now ready to entertain the world and perhaps revive the nation. (...)".

The articles in Latin American newspapers were more enthusiastic, and less critical on the Brazilian situation, probably because of the leading position of that country among Latin republics that have similar contemporary problems and share some kind of Latin solidarity, based on the joint historical and cultural roots. Many critical views on Brazil (political turmoil, recession, crime, protests "No to the Olympics!" etc.), though mixed with some positive aspects ("dances highlighting Brazil's history and rise as an emerging power"), appeared in the article published in "The Guardian" (http://guardian.ng) from Nigeria. Nevertheless, this African newspaper did not notice any element regarding the environment, abundant in the opening ceremony of the Rio 2016.

On the contrary, in several of the analyzed articles the environmental elements of the show were underlined, in others at least mentioned in some paragraphs. Naturally, the articles with headlines that made reference to the environmental issues (so the six mentioned earlier) focused most on these aspects of the opening ceremony and the global environmental problems. Nevertheless, other newspapers noticed it too. The 
Ecuadorian "El Universo" (www.eluniverso.com) underlined the natural resources of Brazil, including Amazonas as "the biggest selva of the world", and noticed that the opening ceremony was to ask people, through television, to take care of the planet. The official daily of the Communist Party of Cuba, "Granma" (www.granma.cu), in the lead paragraph of its article reminded the environmental message of the ceremony: "Pobladores del mundo, salvemos el planeta" ("Inhabitants of the world, let's save the planet"). Also in the lead paragraph of the article in the Portuguese newspaper "Diário de Notícias" (www.dn.pt) the importance of the environment was mentioned, though after recalling the arrival of the Portuguese to Brazil, that was presented at the opening ceremony too. Indeed, some nationalistic views were evident in some of the analyzed articles. Nevertheless, in the Vatican newspaper "L'Osservatore Romano" (www.osservatoreromano.va) an article entitled "Olimpiade di tutti" ("Olympics for everybody") focused more on the team of refugees that participated in the parade of athletes together with national teams during the opening ceremony. The environmental message was mentioned only in the last paragraph, despite the commitment of Pope Francis to the matter.

Also in other newspapers only some mentions on the environmental issues could be read in the analyzed articles. In the Swiss "Le Temps" (www.letemps.ch) a small part of the text was dedicated to the problem of the climate change and "the forest of the athletes" created during the opening ceremony. In the Canadian newspaper "Le Devoir" (www.ledevoir.com) only one sentence, in the middle of the article, informed about allusions to biodiversity and climate change as dangerous for the planet. In "The Nation" (www.nationmultimedia.com) from Thailand it was mentioned only (in a short paragraph, third after the lead of the text) that: "The show is built around the concepts of environmental protection, diversity and joy $(\ldots)$ ". In the "official" English-language "China Daily" (www.chinadaily.com.cn) one could read an article that was a chronological report of the opening ceremony, so some sentences in the middle of the text were dedicated to the environmental aspects of the show. However, the main photo, published under the headline of the article, presented a spectacular view of the fireworks at the Maracana stadium during the ceremony. A similar picture, but showing Maracana (with huge fireworks) from the outside, even more spectacularly, was published in the Brazilian newspaper, based in Rio de Janeiro, "O Globo" (https://oglobo.globo.com), also under the headline of an article, where only some mentions of the environment could be found in the middle of the text reporting the ceremony. Also for the Peruvian "El Comercio" (https://elcomercio.pe) the fireworks at the Maracana stadium was the most important view of the show. The photo was placed under the headline of the article that began with the notion that Brazil celebrated its "exuberant natural resources", and mentioned Amazonas and the "save the planet" message in one of the later paragraphs. In the Colombian newspaper "El Tiempo" (www.eltiempo.com) one could find the same scheme: the fireworks at the Maracana stadium as the main picture and one of the later paragraphs dedicated (not abundantly) to the "green" message from Brazil to the world.

Also in another newspapers some spectacular views from the Maracana stadium were published, though in some cases not only fireworks were the most important image. Some photos with environmental symbols, present during the ceremony, were placed. In the Venezuelan "El Universal" (www.eluniversal.com) the first of a series of photos showed a big green pacifist symbol at the Maracana, though the text did not mention the environmental issues. The same in the Polish newspaper "Rzeczpospolita" (www.rp.pl), where a series of photos included big green Olympic rings, made of trees at the Maracana stadium, though without any mention of the environment in the article. The French newspaper "Le Figaro" (http://lefigaro.fr) offered 
"The fifteen images of the ceremony that should not be missing": two images (the $8^{\text {th }}$ and $11^{\text {th }}$ ) presented the environmental issues, with appropriate comments, and one of them green Olympic rings too. In the Belgian "Le Soir" (www.lesoir.be) one could see ten images of the ceremony, but none of them showed the environmental aspects of the show. Only one comment under one of the photos mentioned that the environment was among themes of the ceremony. The Chilean newspaper "El Mercurio" (www.emol.com) presented a "podium" of the best photos of the ceremony: the Santos Dumont's airplane flying over Rio, fireworks at the Maracana stadium, and finally Indians with green lights, that was an element of the show reviving the history of Brazil, including the nature of Amazonas and the zone of Rio.

In the "Irish Independent" ( $\underline{w w w . i n d e p e n d e n t . i e)}$ a photo of the green pacific symbol at the Maracana stadium appeared, but also another green image was placed there: showing green elements of the sweatshirts of the athletes from the "green island" traveling by bus to the opening ceremony. A mention about "ecology" appeared only after a sentence about supermodel Gisele Bundchen, who "made a guest appearance" during the show (and who was shown on various photos in different newspapers analyzed here): "Celebrating themes of ecology, diversity and joy, the event welcomed 10,500 athletes from more than 200 countries around the world".

\section{Conclusions}

Opening ceremony of the Rio 2016 Olympic Games was watched on TV (live or by retransmissions) by thousands of millions of viewers around the world. Media reports in newspapers were read by another millions of people on all continents. Thanks to this global media coverage the city and country hosting the Olympics could be presented to the global public, that was invaluable in the process of branding Rio de Janeiro and Brazil. The opening ceremony was full of images of Rio and the biggest South American country, but also full of environmental messages, images or allusions. After analyzing 30 important newspapers from different countries of the world, it is possible to conclude that most of them served for branding Rio and Brazil. Rio, because of many expressions, in the headlines as well as in the articles, associated with positive (in general) image of the Olympic Games. Brazil, because of many images presenting the history, cultural and natural values of this country during the opening ceremony, described in the articles (though with some critical views on political or social problems that currently affect Brazil) and shown in the photos. Certainly, such a promotion should attract thousands of new visitors to Rio de Janeiro and Brazil, and should improve the image of these brands (despite some critical views).

The environmental issues were mentioned in most articles, but only in few of them they were underlined or treated as a very important message of the ceremony. As we can see, branding city/country is a more obvious effect of the global media coverage of the Rio 2016 opening ceremony than the promotion of environmental problems. Global ideas are transmitted differently by different media, and another researches may focus on factors that influence it. We can assume that it depends on political bias of the media, as well as cultural background of society in a given country.

In 1994, two years after the Earth Summit in Rio de Janeiro, the International Olympic Committee, in a congress in Paris, declared the environment as the third pillar of the Olympism, in addition to sport and culture. In the opening ceremony of the Rio 2016 the three pillars mixed spectacularly. Although not every 
media report of the ceremony focused on that aspect of the show, the global media impact - even if we were expecting more - should be positive for the planet.

The Olympic Games not only promote sport and hosting cities/countries, but also global ideas, and further research may focus on another problems, like global peace, human rights and so on. Some negative aspects of the Olympics have been dealt by researchers too, like promotion of racism (including Nazism in Berlin 1936), male domination, cheatings and so on. These subjects should not be overlooked in further research on the Olympic Games as global events and promotional "machines" in the context of global communication.

\section{References:}

Aronczyk, M. (2013). Branding the Nation. The Global Business of National Identity. New York: Oxford University Press.

Belloso, J.C. (2011). The City Branding of Barcelona: A Success Story, In: City Branding. Theory and Cases, ed. K. Dinnie. New York: Palgrave Macmillan.

Cox, R. (2010). Environmental Communication and the Public Sphere. Los Angeles: SAGE Publications, Inc.

Cronon, W. (2008). Foreword: Silent Spring and the birth of modern environmentalism, In: DDT, Silent Spring, and the Rise of Environmentalism, ed. T.R. Dunlap. Seattle and London: University of Washington Press.

Dinnie, K. (2011). Introduction to the Practice of City Branding, In: City Branding. Theory and Cases, ed. K. Dinnie. New York: Palgrave Macmillan.

Fola, M. (2011). Athens City Branding and the 2004 Olympic Games, In: City Branding. Theory and Cases, ed. K. Dinnie. New York: Palgrave Macmillan.

Goldblatt, D. (2016). The Games. A Global History of the Olympics. New York: W.W. Norton \& Company. Hansen, A. (2010). Environment, Media and Communication. London and New York: Routledge.

Lester, L. (2010). Media and Environment. Conflict, Politics and the News. Cambridge and Malden: Polity Press.

Longerich, P. (2014). Goebbels. Apostoł diabła. Warszawa: Prószyński i S-ka.

Neuzil, M. (2008). The Environment and the Press. From Adventure Writing to Advocacy. Evanston: Northwestern University Press.

Parratt, S. (2006). Medios de comunicación y medio ambiente. Madrid: Editorial Fragua.

Proszowska-Szala, A., \& Florek, M. (2010). Promocja miast. Nowa perspektywa. Warszawa: Ströer Polska Sp. z o. o.

Romero, S. (2016). A Gilded Olympics Begin With the Opening Ceremony in Gritty Rio, "The New York Times", $\quad$ https://www.nytimes.com/2016/08/06/sports/olympics/summer-games-openingceremony-rio.html (05.08.2016).

Sajna, R. (2012). Planet Earth on the Eve of the Copenhagen Climate Conference 2009: A Study of Prestige Newspapers from Different Continents, "Observatorio Journal", Vol. 6, No. 2 (2012), p. 71-83; http://obs.obercom.pt/index.php/obs/article/view/367.

Tyers, A. (2016). Rio Olympics 2016 opening ceremony kicks off with a vibrant bang - and unfortunate reminders of troubled backdrop to the Games, "The Daily Telegraph", 
http://www.telegraph.co.uk/olympics/2016/08/05/olympics-opening-ceremony-for-rio-2016-live/ (06.08.2016).

Ween, C. (2012). London, England: A Global and Sustainable Capital City, In: Green Cities of Europe, ed. T. Beatley. Washington: Island Press.

\section{List of analyzed articles:}

A Gilded Olympics Begin With the Opening Ceremony in Gritty Rio, https://www.nytimes.com/2016/08/06/sports/olympics/summer-games-opening-ceremonyrio.html (05.08.2016).

Ceremonia otwarcia igrzysk, http://www.rp.pl/Rio-2016/160809468-Ceremonia-otwarcia-igrzysk.html\#ap-1 (06.08.2016).

Brazil invokes history, favelas in a stuning Rio 2016 opening ceremony, http://www.hindustantimes.com/olympics/brazil-invokes-history-favelas-in-a-stunning-rio-2016opening-ceremony/story-P9xUhtkP8UOdgV897KtNhO.html (06.08.2016).

Del homenaje a Santos Dumont a la historia de Brasil: El podio de las mejores fotos del inicio de los JJ.OO., http://www.emol.com/noticias/Deportes/2016/08/06/816042/Del-homenaje-a-Santos-Dumont-alrepaso-a-la-historia-de-Brasil-El-podio-de-las-mejores-fotos-de-la-inauguracion-de-los-JJOO.html (06.08.2016).

El pebetero olímpico ya está encendido, ique empiecen los Juegos!, http://www.eltiempo.com/deportes/otros-deportes/el-pebetero-olimpico-ya-esta-encendido-queempiecen-los-juegos-49349 (05.08.2016).

En marcha la fiesta olímpica de Río 2016, http://www.eluniversal.com/noticias/rio-2016/marcha-fiestaolimpica-rio-2016 430491 (05.08.2016).

Fiesta verdeamarelha en la ceremonia de inauguración de los Juegos Olímpicos, http://www.eluniverso.com/deportes/2016/08/05/nota/5726904/ceremonia-inauguracion-juegosolimpicos-rio-2016-vivo (05.08.2016).

First green, now gold: the climate changes in Rio, http://www.theage.com.au/sport/olympics/rio-2016/firstgreen-now-gold-the-climate-changes-in-rio-20160806-gamhy8.html (06.08.2016).

Glittering ceremony launches Rio Games, https://quardian.ng/sport/olympics-glittering-ceremony-launchesrio-games/ (06.08.2016).

Inauguración Río 2016: revive la espectacular ceremonia, http://elcomercio.pe/deporte-total/inauguracionrio-2016-revive-espectacular-ceremonia-431729 (06.08.2016).

Jogos do Rio abriram em grande. Agora têm a palavra os atletas, http://www.dn.pt/desporto/rio2016/interior/siga-aqui-a-cerimonia-de-abertura-dos-jogos-olimpicos-5324217.html (06.08.2016).

Le stade de Maracanã vibre au rythme d'une cérémonie colorée, http://www.ledevoir.com/sports/actualitessportives/477198/le-stade-maracana-vibre-au-rythme-d-une-ceremonie-coloree (06.08.2016). 
Les dix imagesqu'il ne fallait pas louper de la cérémonie d'ouverture de $J 0$ 2016, http://plus.lesoir.be/53587/article/2016-08-06/les-dix-images-quil-ne-fallait-pas-louper-de-laceremonie-douverture-des-jo-2016 (06.08.2016).

Les quinze images de la cérémonie qu'il ne fallait pas manquer, http://sport24.lefigaro.fr/le-scansport/2016/08/06/27001-20160806ARTFIG00008-les-quinze-images-de-la-ceremonie-qu-il-nefallait-pas-manquer.php (06.08.2016).

Música, arte y ecologismo en inauguración de Juegos, http://www.abc.com.py/internacionales/musica-artey-ecologismo-en-inauguracion-de-rio-2016-1505952.html (05.08.2016).

Noche carioca para una fiesta mundial, http://www.granma.cu/deportes/2016-08-05/noche-carioca-parauna-fiesta-mundial-fotos (05.08.2016).

Olimpiade di tutti, http://www.osservatoreromano.va/it/news/olimpiade-di-tutti (06.08.2016).

Olimpiadi di Rio 2016, via ai Giochi Samba e colori, la grande festa «Non c'è posto migliore del Brasile», http://www.corriere.it/sport/olimpiadi-2016-rio/notizie/olimpiadi-rio-2016-via-giochi-samba-colorigrande-festa-foto-non-c-posto-migliore-brasile-60f8b3a6-5b95-11e6-bfed33aa6b5e1635.shtml?refresh ce-cp (06.08.2016).

Río 2016: "El mejor lugar del mundo es aquí y ahora", ese himno brasileño de Gilberto Gil que se hizo realidad en el Maracaná, http://www.lanacion.com.ar/1925460-rio-2016-el-mejor-lugar-delmundo-es-aqui-y-ahora-ese-himno-brasileno-de-gilberto-gil-que-se-hizo-realidad-en-el-maracana (06.08.2016).

Rio celebra diversidade e passa mensagem de esperança na abertura dos Jogos na Maracanã, https://oglobo.globo.com/esportes/rio-celebra-diversidade-passa-mensagem-de-esperanca-naabertura-dos-jogos-no-maracana-19866473 (06.08.2016).

Río de Janeiro acoge al mundo, http://www.eluniversal.com.mx/articulo/deportes/masdeportes/2016/08/6/rio-de-janeiro-acoge-al-mundo (06.08.2016).

Rio kicks off Olympic opening ceremony, http://www.nationmultimedia.com/news/sports/30292293 (06.08.2016).

Rio leads the world in glitzy samba party at gala Olympic parade, http://www.independent.ie/sport/rio-2016olympics/rio-leads-the-world-in-glitzy-samba-party-at-gala-olympic-parade-34943322.html (06.08.2016).

Rio Olympics open with ceremony focused on environment, http://www.japantimes.co.jp/sports/2016/08/06/olympics/summer-olympics/rio-olympics-openceremony-focused-environment/ (06.08.2016).

Rio Olympics 2016 opening ceremony kicks off with a vibrant bang - and unfortunate reminders of troubled backdrop to the Games, http://www.teleqraph.co.uk/olympics/2016/08/05/olympics-openingceremony-for-rio-2016-live/ (06.08.2016).

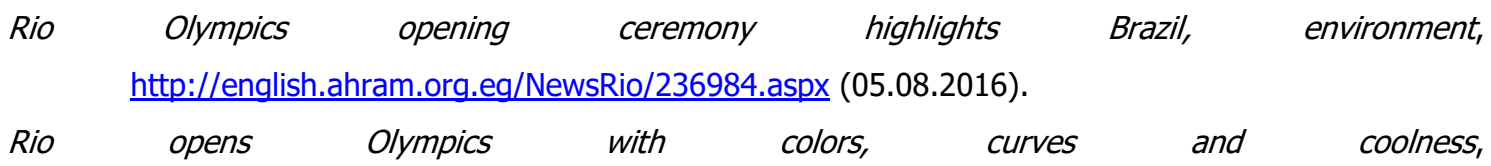
http://www.chinadaily.com.cn/sports/2016rioolympics/2016-08/06/content 26367013.htm (06.08.2016). 
Rio ouvre les Jeux, sans cérémonie, https://www.letemps.ch/sport/2016/08/06/rio-ouvre-jeux-ceremonie (06.08.2016).

Rio welcomes world with sultry music, plea for conservation, http://www.thejakartapost.com/news/2016/08/06/rio-welcomes-world-with-sultry-music-plea-forconservation.html (06.08.2016).

Una

http://www.elmundo.es/deportes/2016/08/06/57a5397eca4741a6118b45f3.html (06.08.2016). 